\title{
Assessment of soil quality after biochar application based on enzymatic activity and microbial composition**
}

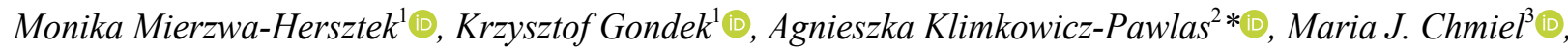 \\ Krzysztof Dziedzic ${ }^{4}$ (1) and Hutsol Taras ${ }^{5}$ (i) \\ ${ }^{1}$ University of Agriculture in Kraków, Department of Agricultural and Environmental Chemistry, Mickiewicza 21, \\ 31-120 Kraków, Poland \\ ${ }^{2}$ Department of Soil Science Erosion and Land Protection, Institute of Soil Science and Plant Cultivation-State Research Institute, \\ Czartoryskich 8, 24-100 Puławy, Poland \\ ${ }^{3}$ Department of Microbiology, University of Agriculture in Kraków, Mickiewicza 24/28, 30-059 Kraków, Poland \\ ${ }^{4}$ Beskid Żywiec Sp. z o.o., Department of Research and Development, Kabaty 2, 34-300 Żywiec, Poland \\ ${ }^{5}$ State Agrarian and Engineering University in Podilya, 13 Shevchenko Str., Kamianets-Podilskyi, Ukraine, 32300
}

Received September 14, 2018; accepted March 11, 2019

\begin{abstract}
Soil microorganisms play a key role in many biochemical processes essential for the environment and for the ecological and production functions of soils, hence they are very important quality indicators. The study aimed at evaluating the effect of 1 and $2 \%$ additions of wheat and miscanthus straw biochars on soil enzymatic activity (dehydrogenases, urease, phosphatases) and the number of microorganisms (bacteria, fungi, actinobacteria). Pot experiments were carried out on soil with a loamy sand texture. The geometric mean of enzyme activities, biological index of fertility, and the integrated total enzyme activity index were used to explore the relationships between soil enzyme activities and the microbiological and chemical properties of soil. The addition of $1 \%$ miscanthus straw biochar had the most beneficial effect on the number of bacteria and fungi (increase by 380 and $26 \%$, respectively), and $1 \%$ wheat straw biochar on the number of actinomycetes (increase by $273 \%$ ). The correlation analysis between the number of actinomycetes and the chemical parameters of the soil showed the significant effect of the content of $\mathrm{N}_{\text {total }}(\mathrm{r}=0.76)$ and $\mathrm{C}_{\text {total }}(\mathrm{r}=0.85)$. The values of biological index of fertility, total enzyme activity index and geometric mean of enzyme activities indexes showed that the best quality of soil was produced by a $2 \%$ addition of wheat straw biochar.

Keywords: biochar, soil, enzymatic activity, microorganisms, soil quality indexes
\end{abstract}

\footnotetext{
*Corresponding author e-mail: agnes@iung.pulawy.pl

**This work was carried out under the project named "Research on forming a model of biochar changes in soil based on the quantitative and qualitative parameters of humus" financed by the National Science Centre (project No.: 2015/17/N/NZ9/01132).
}

\section{INTRODUCTION}

In recent years, the quality and health of soil fertilized with biochar has been of great interest to a wide range of scientists around the world (Vithanage et al., 2018). Although the boundary between the two concepts is not clearly defined, it is assumed that "soil quality" refers to the soil's ability to perform certain functions, while "soil health" refers to its overall state (Tian et al., 2016; Liu et al., 2017). Despite the significant number of scientific papers describing the effect of biochar on the soil, only a small proportion of them estimate and quantify the quality parameters of the soil. This probably reflects not only the difficulties in finding appropriate, integrated quantitative indicators for the assessment of soil quality, but also the ability to interpret them. This problem could be solved by aggregating data concerning the chemical, physical, and biological properties of soil in the form of numerical indexes, which include, among other factors, the geometric mean of enzyme activities (GMea), the biological index of fertility $(B I S F)$, and the integrated total enzyme activity index (TEI) (Paz-Fereiro et al., 2012; Tan et al., 2014). The determination of the enzymatic activity constituting the core of each of these indexes and the microbiocenotic composition of soil is one of the most rapid and sensitive ways of indicating the natural and anthropogenic changes in the

(C) 2019 Institute of Agrophysics, Polish Academy of Sciences (c) (1) (8) $\Theta$ 
soil (Gul et al., 2015; Mierzwa-Hersztek et al., 2017; Liu et al., 2017). Firstly, soil enzymes are measures of the activity of microorganisms involved in biochemical processes, such as the mineralization and synthesis of organic substances, as well as the circulation of nutrients (Gul et al., 2015; Tian et al., 2016). Secondly, a significant volume of research indicates that changes in the physical and chemical properties of soil have an effect on enzymatic activity, and that quantitative and qualitative changes in microbial populations have a significant impact on the functional integrity of soil (Khadem and Raiesi, 2017; Beheshti et al., 2018). These changes have a direct impact on the living conditions of plants, which in turn affects the quantity and quality of the biomass obtained. For this reason, studies on soil that involve methods based on enzymatic tests and the assessment of microbiological composition allow for a comprehensive verification of changes that take place in soil after fertilization, including fertilization with biochar (Ameloot et al., 2013; Vithanage et al., 2018). Due to its unique properties, biochar is considered to be a perfect source of mineral substances. The addition of biochar to the soil may lead to significant changes in the structural and functional diversity of the microbial population, and thus affect their activity.

However, data concerning the effect of different types of biochar on the activity and abundance of soil microorganisms are still limited and contradictory. A study was conducted to evaluate the effect of 1 and $2 \%$ additions of wheat (WSB) and Miscanthus giganteus (MSB) straw biochars on: soil enzymatic activity (dehydrogenases, urease, acid and alkaline phosphatase) and the number of soil microorganisms. An additional aim was to explore the relationships between soil enzyme activities and chemical and microbiological properties using three different indexes: $T E I, B I S F$, and GMea.

\section{MATERIALS AND METHODS}

The biochars were produced from miscanthus and wheat straws, which were previously dried at ambient temperature, ground in a laboratory mill (mesh size of $4 \mathrm{~mm}$ ), and mixed to ensure homogeneity. The straws were pyrolysed in an electric laboratory furnace at $300^{\circ} \mathrm{C}$ for $15 \mathrm{~min}$ under a limited supply of air (IBI, 2014).

The pot experiment was carried out in the greenhouse of the University of Agriculture on soil with a loamy sand texture collected from the $0-0.2 \mathrm{~m}$ layer. The experiment consisted of 6 treatments carried out in 3 replications: 0 - control soil (soil without additives), MF - soil with the addition of pure mineral salts, WSB - soil with the addition of mineral salts (MF) and wheat straw biochar of $1 \%$ (WSB $1 \%$ ) and 2\% (WSB 2\%), and MSB - soil with the addition of mineral salts (MF) and miscanthus straw biochar of $1 \%$ (MSB 1\%) and 2\% (MSB 2\%). The nutrients were introduced into the soil as mineral salts at the following doses:
0.10, 0.04 and $0.12 \mathrm{~g} \mathrm{~kg}^{-1} \mathrm{DM}$ of soil, for $\mathrm{N}$ (ammonium nitrate $-\mathrm{NH}_{4} \mathrm{NO}_{3}$ ), $\mathrm{P}$ (monocalcium phosphate monohydrate $-\mathrm{Ca}\left(\mathrm{H}_{2} \mathrm{PO}_{4}\right)_{2} \mathrm{H}_{2} \mathrm{O}$ ) and $\mathrm{K}$ (potassium chloride $-\mathrm{KCl}$ ), respectively. After the application of biochars and mineral salts and mixing them with the soil, the seeds of perennial ryegrass were sown. During the experiment, the humidity of the soils was maintained at a constant level of $45 \%$ of the WHC. Soil for microbiological and biochemical analyses was collected 6 months after biochar application and stored at $4{ }^{\circ} \mathrm{C}$ for biological analysis and at $25^{\circ} \mathrm{C}$ for physicochemical analysis.

The following parameters were determined for the soils and biochars: $\mathrm{pH}_{\mathrm{KCl}}$ and $\mathrm{pH}_{\mathrm{H} 2 \mathrm{O}}$ using the potentiometric method, electrical conductivity (EC) which was measured conductometrically, the content of total nitrogen $\left(\mathrm{N}_{\text {total }}\right)$ and carbon $\left(\mathrm{C}_{\text {total }}\right)$ using a CNS analyser (Vario MAX Cube, Elementar Analysensysteme, GmbH, Germany). The total content of trace elements in the soil and biochars was determined using the ICP - OES method on the Perkin Elmer Optima 7300DV apparatus according to the methodology described in an earlier study by Mierzwa-Hersztek et al. (2017). The specific surface area $\left(S_{\mathrm{BET}}\right)$, pore volume and diameter of the biochars were determined using the multifunction accelerated surface area and porosimetry analyser ASAP 2010 (Micrometics, USA).

The measurement of the soil biological activity included the number and enzymatic activity of soil microorganisms. The evaluation of the number of selected groups of soil microorganisms was carried out using the serial dilution method developed by Koch with a number of microbiological substrates. The following groups of microorganisms were determined: bacteria (Trypticasein Soy Lab Agar, BTL, Poland, grown at $37^{\circ} \mathrm{C}$, for $24 \mathrm{~h}$ ), mould fungi (Malt Extract Agar, BTL, Poland, grown at $28^{\circ} \mathrm{C}$, for 5 days) and actinomycetes (Actinomycete Isolation Lab Agar, Biocorp, Poland, grown at $28^{\circ} \mathrm{C}$, for 7 days). The number of colonyforming units (CFU) of microorganisms was determined by the dilution culture method.

The evaluation of dehydrogenase (EC 1.1.1.1) activity was performed using the method of Thalmann (1968), urease (EC 3.5.1.5) activity by the Zantua and Bremner (1975) method and acid and alkaline phosphatase (EC 3.1.3.1) activities with the Allef and Nannipieri (1995) method. In order to integrate the information obtained and to compare data, three different indexes were calculated. The integrated TEI index was calculated using the following Eq. (1) (Tan et al., 2014):

$$
T E I=\sum_{n=1}^{I} \frac{X_{i}}{\overline{X_{i}}}(n=1,2,3, \mathbf{4}),
$$

where: $X_{i}$ is the activity of the soil enzyme $i$ and $\bar{X}_{i}$ is the mean activity of enzyme $i$ in all samples.

The geometric mean of enzyme activities (GMea) was calculated using a method discussed elsewhere (PazFerreiro et al., 2012) as follows: 


$$
G M e a=\sqrt[4]{D h A \times U r e \times A l P \times A c P} .
$$

The BISF index was calculated as follows (Bastida et al., 2008):

$$
B I S F=\sqrt{M f^{2}+A c t^{2}+\text { Corg }^{2}+C E C^{2}} \cdot 100 \% .
$$

where: $M f$ - number of mould fungi $\left(\times 10^{-3} \mathrm{CFU} \mathrm{g}^{-1} \mathrm{DM}\right)$,

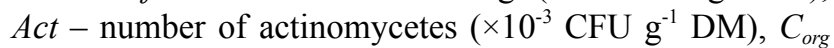
- organic carbon content $\left(\mathrm{g} \mathrm{kg}^{-1}\right), C E C$ - cation exchange capacity $\left(\mathrm{mmol}(+) \mathrm{kg}^{-1}\right)$.

The differences between treatments were evaluated using a one-way analysis of variance (ANOVA, Duncan test, $p \leq 0.05$ ). The variation within treatments was determined by calculating the standard deviation $( \pm$ SD). The correlation coefficients between the chemical and biological properties of soil were calculated using Spearman's nonparametric test. All statistical analyses were performed using Statistica PL 13 software (StatSoft Inc.).

\section{RESULTS AND DISCUSSION}

The soil used in the experiment was slightly acidic $\mathrm{pH}_{\mathrm{H}_{2} \mathrm{O}}(5.67)$ and had a relatively low $\mathrm{C}_{\text {total }}\left(6.43 \mathrm{~g} \mathrm{~kg}^{-1}\right)$ and $\mathrm{N}_{\text {total }}\left(0.54 \mathrm{~g} \mathrm{~kg}^{-1}\right)$ content. The biochars applied in the experiment had similar values of $\mathrm{pH}_{\mathrm{H}_{2} \mathrm{O}}$ (WSB: 6.52 and, and MSB 6.28), EC (WSB: $378 \mu \mathrm{S} \mathrm{cm}^{-1}$, and MSB: $345 \mu \mathrm{S} \mathrm{cm}^{-1}$ ), and $\mathrm{C}_{\text {total }}$ content (WSB: $628 \mathrm{~g} \mathrm{~kg}^{-1}$, and MSB: $651 \mathrm{~g} \mathrm{~kg}^{-1}$ ).
In contrast to miscanthus straw biochar, wheat straw biochar (WSB) had a larger specific surface area $\mathrm{S}_{\mathrm{BET}}$, and a higher content of $\mathrm{N}_{\text {total }}$. A more detailed description of the biochars used is given in Mierzwa-Hersztek et al. (2017).

The dose of biochar is considered one of the main factors determining the effectiveness of this material in the process of changing soil properties (Tian et al., 2016). The application of WSB and MSB biochars to the soil at $1 \%$ and $2 \%$ doses significantly $(\mathrm{p} \leq 0.05)$ increased the soil $\mathrm{pH}$ compared to the treatment which was only fertilized with mineral salts (MF) (Table 1), however, changes in the $\mathrm{pH}$ were more definite in combination with a WSB biochar. Treatment with mineral salts (MF) significantly decreased soil reaction $(\mathrm{pH})$ against all other treatments, including the control treatment (Table 1). Lošák et al. (2012) described the effect of mineral fertilizers on soil reaction changes. The value of CEC significantly increased (by $85 \%$ ) only after the MSB $2 \%$ treatment and was $130 \mathrm{mmol}(+) \mathrm{kg}^{-1}$. The content of $\mathrm{C}_{\text {total }}$ and $\mathrm{N}_{\text {total }}$ also increased relative to the applied doses of WSB and MSB biochars. Compared to the MF treatment, the $\mathrm{C}_{\text {total }}$ content after WSB and MSB treatments applied at 1 and $2 \%$ doses increased by: 86, 146, 79, $139 \%$, respectively, while the $\mathrm{N}_{\text {total }}$ content increased by: $22,41,10,16 \%$.

WSB and MSB application significantly affected the abundance of microbial groups and the patterns of the microbial community (Table 2). The dominant group of microorganisms were bacteria, as their numbers peaked in

Table 1. Selected soil properties after 6 months of the experiment

\begin{tabular}{cccccc}
\hline Treatment & $\mathrm{pH} \mathrm{H} \mathrm{H}_{2}$ & $\mathrm{EC}\left(\mu \mathrm{S} \mathrm{cm}^{-1}\right)$ & $\begin{array}{c}\mathrm{CEC}(\mathrm{mmol}(+) \\
\left.\mathrm{kg}^{-1}\right)\end{array}$ & $\mathrm{C}_{\text {total }}\left(\mathrm{g} \mathrm{kg}^{-1}\right)$ & $\mathrm{N}_{\text {total }}\left(\mathrm{g} \mathrm{kg}^{-1}\right)$ \\
\hline $\mathrm{C}$ & $5.94 \mathrm{~b} \pm 0.24$ & $34.7 \mathrm{a} \pm 6.35$ & $59.1 \mathrm{a} \pm 7.34$ & $5.70 \mathrm{a} \pm 0.13$ & $0.45 \mathrm{a} \pm 0.03$ \\
MF & $5.52 \mathrm{a} \pm 0.08$ & $56.0 \mathrm{~b} \pm 3.00$ & $70.4 \mathrm{~b} \pm 10.8$ & $5.86 \mathrm{a} \pm 0.23$ & $0.49 \mathrm{ab} \pm 0.03$ \\
WSB 1\% & $6.09 \mathrm{bc} \pm 0.17$ & $70.7 \mathrm{c} \pm 6.11$ & $77.0 \mathrm{~b} \pm 8.00$ & $10.9 \mathrm{~b} \pm 1.36$ & $0.60 \mathrm{c} \pm 0.06$ \\
WSB 2\% & $6.31 \mathrm{c} \pm 0.09$ & $82.0 \mathrm{c} \pm 1.42$ & $80.2 \mathrm{~b} \pm 6.61$ & $14.4 \mathrm{c} \pm 1.42$ & $0.69 \mathrm{~d} \pm 0.02$ \\
MSB 1\% & $5.83 \mathrm{~b} \pm 0.14$ & $56.0 \mathrm{~b} \pm 2.95$ & $74.5 \mathrm{~b} \pm 1.47$ & $10.5 \mathrm{~b} \pm 0.48$ & $0.54 \mathrm{c} \pm 0.01$ \\
MSB 2\% & $5.91 \mathrm{~b} \pm 0.15$ & $45.0 \mathrm{ab} \pm 2.00$ & $130 \mathrm{c} \pm 10.5$ & $14.0 \mathrm{c} \pm 1.47$ & $0.57 \mathrm{c} \pm 0.03$ \\
\hline
\end{tabular}

Each value represents the mean of three replicates \pm standard deviation; mean values marked with the same letters in the column do not differ significantly according to Duncan's test at $\mathrm{p} \leq 0.05$, factor: fertilization, $\mathrm{C}-$ control (soil without additives), MF - mineral fertilization (NPK),WSB $1 \%$ and WSB $2 \%-$ NPK + wheat straw biochar of 1 and $2 \%$, respectively, MSB $1 \%$ and MSB $2 \%-$ NPK + miscanthus straw biochar of 1 and $2 \%$, respectively.

Table 2. Average number of microorganisms in soil after the application of biochars

\begin{tabular}{cccc}
\hline \multirow{2}{*}{ Treatment } & Bacteria & $M f$ & Act \\
\cline { 2 - 4 } & & $\left(\times 10^{-3} \mathrm{CFU} \mathrm{g}^{-1} \mathrm{DM}\right)$ & $239 \mathrm{a} \pm 37$ \\
C & $920 \mathrm{ab} \pm 99$ & $386 \mathrm{c} \pm 6$ & $291 \mathrm{a} \pm 34$ \\
MF & $681 \mathrm{a} \pm 48$ & $247 \mathrm{ab} \pm 19$ & $1088 \mathrm{c} \pm 91$ \\
WSB 1\% & $1077 \mathrm{~b} \pm 98$ & $275 \mathrm{ab} \pm 22$ & $1666 \mathrm{~d} \pm 54$ \\
WSB 2\% & $1341 \mathrm{~b} \pm 141$ & $218 \mathrm{a} \pm 34$ & $328 \mathrm{~b} \pm 56$ \\
MSB 1\% & $1363 \mathrm{c} \pm 366$ & $398 \mathrm{c} \pm 43$ & $496 \mathrm{~b} \pm 47$ \\
\hline
\end{tabular}

Explanations identical to those of Table 1. 
Table 3. Spearman's correlation coefficients between the selective soil chemical and biological properties $(n=3)$

\begin{tabular}{|c|c|c|c|c|c|c|c|c|c|c|}
\hline Parameter & $\mathrm{B}^{1}$ & $M f^{2}$ & $A c t^{3}$ & DhA & Ure & AlP & $\mathrm{AcP}$ & GMea & $B I S F$ & $T E I$ \\
\hline $\mathrm{pH}$ & $0.49 *$ & -0.16 & $0.59 *$ & $0.58 *$ & $0.60 * *$ & $0.70 * *$ & 0.06 & $0.65 * *$ & $0.77 * * *$ & $0.72 * * *$ \\
\hline $\mathrm{EC}$ & 0.28 & -0.56 & $0.61 * *$ & 0.15 & 0.43 & 0.32 & 0.35 & $0.47 *$ & $0.48 *$ & 0.39 \\
\hline $\mathrm{CEC}$ & 0.27 & -0.12 & $0.57 *$ & -0.35 & $0.61 * *$ & -0.08 & $0.54 *$ & 0.31 & $0.58 *$ & 0.29 \\
\hline $\mathrm{C}_{\text {total }}$ & $0.51 *$ & -0.18 & $0.76 * * *$ & $0.85 * * *$ & $0.90 * * *$ & 0.33 & $0.49 *$ & $0.73 * * *$ & $0.79 * * *$ & $0.69 * *$ \\
\hline $\mathrm{N}_{\text {total }}$ & $0.58 *$ & -0.41 & $0.85 * * *$ & 0.21 & $0.83 * * *$ & $0.51 *$ & 0.46 & $0.79 * * *$ & $0.76 * * *$ & $0.85 * * *$ \\
\hline
\end{tabular}

Bold values statistically significant at the: ${ }^{*} \mathrm{p} \leq 0.05$ level, ${ }^{* *} \mathrm{p} \leq 0.01$ level, ${ }^{* * *} \mathrm{p} \leq 0.001$ level. ${ }^{1}$ Bacteria, ${ }^{2}$ Mould fungi, ${ }^{3}$ Actinomyces.

the soil with the addition of MSB $1 \%$. The $\mathrm{pH}(\mathrm{r}=0.49$, $\mathrm{p} \leq 0.05), \mathrm{C}$ content $(\mathrm{r}=0.51, \mathrm{p} \leq 0.05)$ and $\mathrm{N}$ content $(\mathrm{r}=0.58 ; \mathrm{p} \leq 0.05)$ (Table 3$)$ mainly affected the number of bacteria. A positive correlation between the number of microorganism populations and $\mathrm{pH}$ as well as the $\mathrm{C}$ and $\mathrm{N}$ contents was also demonstrated by Khadem and Raiesi (2017). Compared to the MF treatment, the number of actinomycetes also significantly $(\mathrm{p} \leq 0.05)$ increased after the application of both doses of WSB and MSB biochars; however, the effect of wheat straw biochar was more pronounced, regardless of the dose applied. The addition of WSB biochar increased the number of actinomycetes by $231 \%$ (WSB 1\%) and by $236 \%$ (WSB 2\%) compared to treatments with various doses of MSB applied. The correlation analysis between the number of actinomycetes and the chemical parameters of the soil showed the significant effect of $\mathrm{pH}(\mathrm{r}=0.59, \mathrm{p} \leq 0.05), \mathrm{EC}(\mathrm{r}=0.61, \mathrm{p} \leq 0.01)$ and CEC ( $r=0.57, p \leq 0.05)$, however it had the greatest effect on the content of $\mathrm{N}_{\text {total }}(\mathrm{r}=0.76 ; \mathrm{p} \leq 0.001)$ and $\mathrm{C}_{\text {total }}(\mathrm{r}=$ $0.85, \mathrm{p} \leq 0.001)$. The opposite effect of biochar was noted in the case of fungi, a greater number of these microorganisms was determined for soils with the addition of MSB biochar (Table 2).

The biological processes shaping soil fertility and productivity are mainly connected with the activity of soil microorganisms translating into the number of enzymes produced (Beheshti et al., 2018). Changes in enzyme activity reflect the trends in soil biochemical processes as well as all transformations related to soil biology and its physical and chemical properties. The activity of each of the four enzymes associated with the $\mathrm{C}, \mathrm{N}$ and $\mathrm{P}$ cycles, analysed in our study are shown in Fig. 1 . The highest activity level of dehydrogenase (DhA), urease (Ure) and alkaline phosphatase (AIP) was observed in soil with a $2 \%$ addition of WSB. Compared to the MF treatment, the DhA activity significantly increased only in treatments with a 1 and $2 \%$ addition of WSB (by 34 and 58\%, respectively). The addition of MSB, especially at a $2 \%$ dose, significantly reduced the DhA activity. In the case of Ure, a significant ( $p \leq 0.05$ ) increase in the enzyme activity was observed in each treatment amended with biochars - relative to the amount of biochar applied. The Ure activity was mainly dependent on the $\mathrm{C}(\mathrm{r}=0.90, \mathrm{p} \leq 0.001)$ and $\mathrm{N}(\mathrm{r}=0.83$, $\mathrm{p} \leq 0.001$ ) content in the soil (Table 3 ). The results obtained confirm the conclusions of other authors who observed both the positive (Tian et al., 2016; Mierzwa-Hersztek et al., 2017; Vithanage et al., 2018) and negative (Lammirato et al., 2011; Ameloot et al., 2013) impact of biochar on soil enzymatic activity.

As in the case of DhA, the AlP activity significantly increased only in the soil amended with WSB, as opposed to the results of the MF treatment (Fig. 1). In the case of AcP, a more substantial positive effect was observed at the lowest dose (1\%) of both biochars and the activity of this enzyme increased by $30 \%$ and $40 \%$, respectively. We also demonstrated that a $2 \%$ addition of WSB and MSB biochar decreased the activity of AcP by $17 \%$ on average compared to the soil with a $1 \%$ addition of these materials. In the
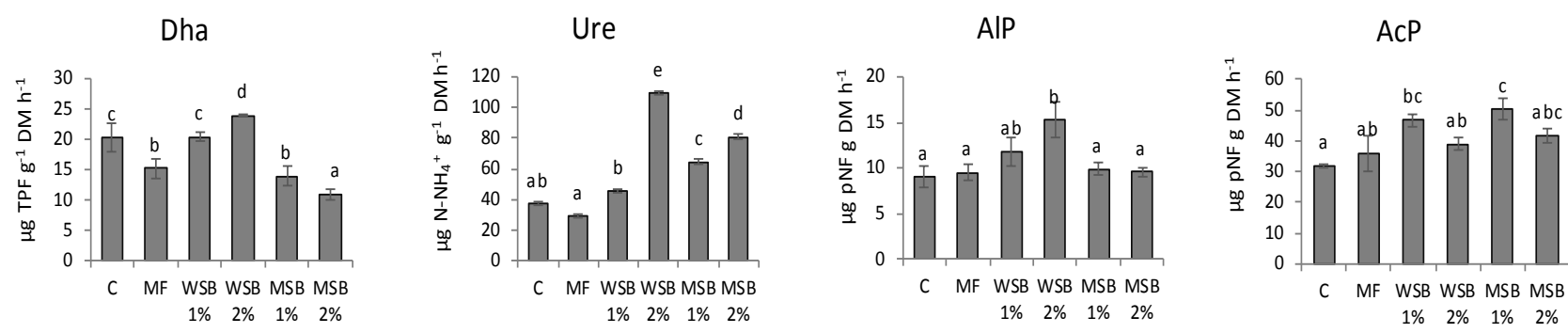

Fig. 1. Enzymatic activity of soil with the addition of biochar. Explanations identical to those of Table 1. 

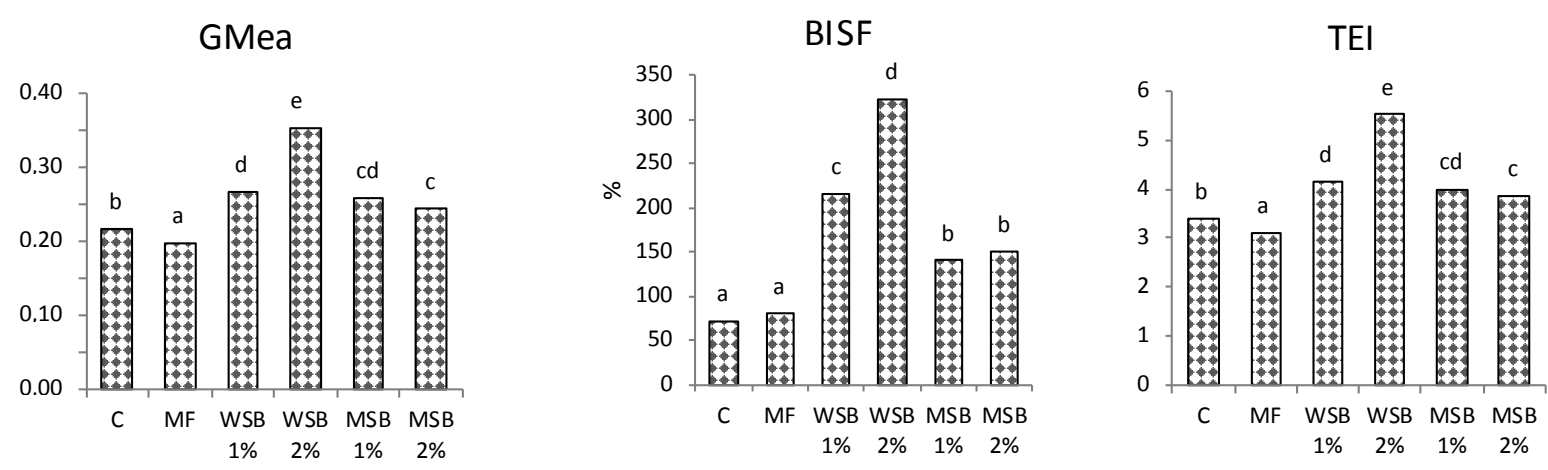

Fig. 2. Geometric mean of enzyme activities (GMea), biological index of fertility $(B I S F)$ and the integrated total enzyme activity index (TEI) for different treatments. Refer to Table 1 for other explanations.

study of Demisie and Zhang (2015), the application of oak wood biochar and bamboo biochar at the same doses (1 and $2 \%$ ) did not significantly increase the phosphatase activity. However, these authors found significantly higher values of phosphatase activity in the analysed soils (from 115 to $149 \mu \mathrm{g} \mathrm{pNP} \mathrm{g}^{-1} \mathrm{DM} \mathrm{h}^{-1}$ ). These differences may be due to the $\mathrm{C}$ and $\mathrm{N}$ content and the $\mathrm{pH}$ and $\mathrm{CEC}$ of the soil, as phosphatases are very sensitive to changes in these parameters (Paz-Ferreiro et al., 2012). This theory was also confirmed by the correlation analysis in our studies (Table 3 ).

The importance of using indexes to determine soil quality was already highlighted 10 years ago, among others, by Bastida et al. (2008). Multi-parameter indexes are recommended to assess the effect of the method of fertilization used on changes in the edaphic environment, because they are less sensitive to seasonal and spatial variations (PazFerreiro et al., 2012; Vithanage et al., 2018). The following three integrated indexes were used in our study: GMea, $B I S F$ and TEI, taking into account the enzymatic activity of the analysed soils. The geometric mean of enzyme activities (GMea) calculated in our study shows that the use of both types and doses of biochars significantly increased the soil enzymatic activity (Fig. 2). However, the application of WSB biochar was much more advantageous for the soil. Lower GMea values and a significantly lower number of all microorganisms (Table 2) for soils with the addition of MSB suggest that the use of this type of biochar has a much lower impact on the biological parameters of the soil. This may be due to the lower content of nutrients in MSB, such as nitrogen, or their lower availability. The biological index of soil fertility $(B I S F)$ allows for the estimation of the effect of fertilization on the quality of the soil, and the integrated total enzyme activity index (TEI) allows for a straightforward comparison between the combined enzyme activity and the quality of each soil sample. The obtained values of $B I S F$ for soil from individual treatments ranged from 87.5 (MF) to 150 (WSB 2\%), and values of TEI from 3.10 (MF) to 5.52 (WSB $2 \%$ ). The calculated $B I S F$ values, which take into account various biological and chemical parameters, and the TEI values confirmed that after the addition of WSB the soil had significantly better fertility than the soil fertilized with MSB biochar. According to Tan et al. (2014), TEI is usually positively correlated with the content of $\mathrm{C}$ and $\mathrm{N}$, which was also confirmed in our study (Table 3). The analysis of soil properties confirmed the more beneficial effect of WSB on the N content. This also resulted in a reduced $\mathrm{C}: \mathrm{N}$ ratio in treatments with WSB, which undoubtedly promoted the intensified mineralization of organic substances and the release of mineral forms of $\mathrm{N}$. The values of GMea, TEI and BISF indexes also significantly depended on soil $\mathrm{pH}$.

Our results indicate that the interaction of many factors greatly influence the effect of biochar on the enzymatic activity of the soil and its microbiocenotic composition. Due to their different specific surface areas $\mathrm{S}_{\mathrm{BET}}$, the size and diameter of pores, as well as chemical composition, the biochars used had different effects on soil properties, which was also observed by Tian et al. (2016) and Vithanage et al. (2018). However, there is still a lack of comprehensive reports concerning the dynamics of changes and the effect of biochar addition on changes in the amount and activity of soil microorganisms.

\section{CONCLUSIONS}

1. It was demonstrated that both the type and the dose of the biochars used had a significant effect on the biological activity of the soil. The response of the soil microorganisms differed in relation to the type of parameter tested.

2. The application of wheat and Miscanthus giganteus straw biochars significantly affected the abundance of microbial groups and the patterns of the microbial community; a significant increase in the number of bacteria and actinomycetes was observed after the application of wheat straw biochar.

3. The type of biochar added had another significant effect on soil enzymatic activity; the highest degree of activity was determined for soil with the addition of wheat straw biochar. 
4. The values of the biological index of soil fertility, total enzyme activity and geometric mean of enzyme acti vities indexes showed that the best soil quality resulted from a $2 \%$ addition of wheat straw biochar.

Conflict of interest: The Authors do not declare any conflict of interest.

\section{REFERENCES}

Allef K. and Nannipieri P., 1995. Methods in applied soil microbiology and biochemistry (enzyme activites). Academic Press, London, UK.

Ameloot N., Neve S.D., Jegajeevagan K., Yildiz G., Buchan D., Funkuin Y.N., Prins W., Bouckaert L., and Sleutel S., 2013. Short-term $\mathrm{CO}_{2}$ and $\mathrm{N}_{2} \mathrm{O}$ emissions and microbial properties of biochar amended sandy loam soils. Soil Biol. Biochem., 57, 401-410. https://doi.org/10.1016/j. soilbio.2012.10.025

Bastida F., Zsolnay A., Hernández T., and García C., 2008. Past, present and future of soil quality indices: a biological perspective. Geoderma, 147, 159-171. https://doi. org/10.1016/j.geoderma.2008.08.007

Beheshti M., Etesami H., and Alikhani H.A., 2018. Effect of different biochars amendment on soil biological indicators in a calcareous soil. Environ. Sci. Pollution Res., 1-10. https://doi.org/10.1007/s11356-018-1682-2

Demisie W. and Zhang M., 2015. Effect of biochar application on microbial biomass and enzymatic activities in degraded red soil. Afr. J. Agricult. Res., 10(8),755-766. https://doi. org/10.5897/ajar2013.8209

Gul S., Whalen J.K., Thomas B.W., Sachdeva V., and Deng H.Y., 2015. Physico-chemical properties and microbial responses in biochar-amended soils: mechanisms and future directions. Agric. Ecosyst. Environ., 206, 46-59. https://doi. org/10.1016/j.agee.2015.03.015

IBI, 2014. Standardized Product Definition and Product Testing Guidelines for Biochar that Is Used in Soil. http://www.biochar-international.org/characterizationstandard

Khadem A. and Raiesi F., 2017. Responses of microbial performance and community to corn biochar in calcareous sandy and clayey soils. Appl. Soil Ecol., 114, 16-27. https://doi. org/10.1016/j.apsoil.2017.02.018

Lammirato C., Miltner A., and Kaestner M., 2011. Effects of wood char and activated carbon on the hydrolysis of cello- biose by b-glucosidase from Aspergillus niger. Soil Biol. Biochem., 43, 1936-1942. https://doi.org/10.1016/j. soilbio.2011.05.021

Lošák T., Čermák P., and Hlušek J., 2012. Changes in fertilization and liming of soils of the Czech Republic for the last 20 years. Arch. Agron. Soil Sci., 58, 238-242.

Liu X., Guo K., Huang L., Ji Z., Jiang H., Li H., and Zhang J., 2017. Responses of absolute and specific enzyme activity to consecutive application of composted sewage sludge in a Fluventic Ustochrept. PLoS ONE 12(5), e0177796. https://doi.org/10.1371/journal.pone.0177796

Mierzwa-Hersztek M., Gondek K., Klimkowicz-Pawlas A., and Baran A., 2017. Effect of wheat and miscanthus straw biochars on soil enzymatic activity, ecotoxicity, and plant yield. Int. Agrophys., 31, 367-375. https://doi.org/10.1515/ intag-2016-0063

Paz-Ferreiro J., Gascó G., Gutierrez B., and Mendez A., 2012. Soil biochemical activities and geometric mean of enzyme activities after application of sewage sludge and sewage sludge biochar to soil. Bil Fertil Soils, 48, 511-517. https:// doi.org/10.1007/s00374-011-0644-3

Tan X., Xie B., Wang J., He W., Wang X., and Wei G., 2014. County-scale spatial distribution of soil enzyme activities and enzyme activity indices in agricultural land: implications for soil quality assessment. The Scientific World J., ID 535768, https://doi.org/10.1155/2014/535768

Tian J., Wang J., Dippold M., Gao Y., Blagodatskaya E., and Kuzyakov Y., 2016. Biochar affects soil organic matter cycling and microbial functions but does not alter microbial community structure in a paddy soil. Sci. Total Environ., 556, 89-9. https://doi.org/10.1016/j.scitotenv.2016.03.010

Thalmann A., 1968. Methods of dehydrogenase activity determination with triphenyltetrazoliumchlorid (TTC) (in German). Landwirtsch. Forsch, 21, 249-258.

Vithanage M., Bandara T., Al-Wabel M.I., Abduljabbar A., Usman A.R.A., Ahmad M., and Ok Y.S., 2018. Soil enzyme activities in waste biochar amended multi-metal contaminated soil; effect of different pyrolysis temperatures and application rates. Communications in Soil Science and Plant Analysis, 49(5), 635-643. https://doi.org/10.1080 /00103624.2018.1435795

Zantua M.I. and Bremner J.M., 1975. Comparison of methods of assaying urease activity in soils. Soil Biol. Biochem., 7, 291-295. https://doi.org/10.1016/0038-0717(75)90069-3 